\title{
PENGARUH PROFESIONALISME DAN OBJEKTIFITAS AUDITOR TERHADAP KETEPATAN PEMBERIAN OPNI AUDIT
}

\author{
Hari Stiawan \\ Universitas Pamulang \\ Haristiawan33@gmail.com
}

\begin{abstract}
Abstrak
Tujuan dari penelitian ini adalah untuk mengetahui seberapa besar pengaruh profesioanlisme dan objektifitas auditor terhadap ketepatan pemberian opini pada Akuntan Publik Wilayah Jakarta Selatan, baik secara parsial maupun simultan. Jenis penelitian ini adalah kausalitas, mengunakan data primer melalui penyebaran kuisioner pada KAP di Wilayah Jakarta Selatan Respondennya adalah auditor, pengambilan sampel dilakukan dengan metode sampel random sampling, unit analisis adalah auditor, serta data analisis dengan menggunakan Analisis regresi linier berganda. Hasil penelitian menunjukan bahawa secara simultan Variabel profesionalisme, dan objektifitas berpengaruh signifikan terhadap ketepatan pemberian opini audit. Secara parsial menunjukan bahwa variabel profesionalisme dan objektifitas auditor berpengaruh secara signifikan terhadap ketepatan pemberian opini audit, Adjusted R square 65,5\%, sisanya 34,5\% di pengaruhi oleh variabel lain.
\end{abstract}

Kata Kunci : Profesionalisme, objektifitas dan Ketepatan pemberian opini.

\begin{abstract}
The purpose of this research is to find out how much influence the professionalism and objectivity of the auditor on the accuracy of giving opinion to the Public Accountant in the South Jakarta, both partially and simultaneously. This type of research is causality, using primary data through distributing questionnaires to KAP in the South Jakarta. Respondents are auditors, Sampling was done by random sampling method, The unit of analysis is the auditor, as well as data analysis using multiple linear regression analysis. The results showed that simultaneously the variables of professionalism and objectivity had a significant effect on the accuracy of the provision of audit opinions. Partially, it shows that the professionalism and objectivity variables influence significantly on the accuracy of the provision of audit opinions, adjusted $R$ square $65.5 \%$, the remaining $34.5 \%$ is influenced by other variables.
\end{abstract}

Keywords: Professionalism, objectivity and accuracy of giving opinions 
Vol.1, No.3, Sept 2018

\section{PENDAHULUHAN}

Auditor sebagai pihak yang dipercaya oleh publik, auditor akan memeriksa laporan keuangan lalu mengeluarkan sebuah pernyataan. Auditor diberikan kepercayaan yang besar dari para pemangku kepentingan atas laporan keuangan inilah yang akhirnya mewajibkan auditor menjaga kualitas audit yang dihasilkannya. walaupun pertanyaan besar dari para pemangku kepentingan (eksternal) tentang kualitas audit yang dihasilkan oleh auditor, dikarnakan banyak skandal yang melibatkan auditor.

Ada banyak masalah tentang etika profesi auditor yang menyebutkan auditor melakukan fraud dalam memeriksa laporan keuangan perusahaan. Hal ini biasanya dikarnakan adanya tekanan psikologis yang diterima oleh auditor, munculnya kekhawatiran akuntan apabila tidak memberikan pendapat yang positif maka diperiode yang akan di depan tidak akan menggunakan kembali jasanya, karena meskipun Kantor Akuntan Publik independen tetapi perusahaan yang membayar jasanya. Misalnya kasus yang terbaru pada tahun 2015 yaitu kasus Toshiba di jepang yang sejak tahun 2008 hingga tahun 2015 telah ditemukan 3 (tiga) direksi telah berperan aktif dalam menggelembungkan laba sebesar ¥151,8 miliar (setara dengan Rp 15,85 triliun). Dalam kasus ini akuntan independen yang mengaudit laporan keuangan Toshiba yaitu KPMG seharusnya dapat mengetahui kecurangan tersebut karena nilainya sangat material.

Menurut Anggun (2010) Profesionalisme juga menjadi syarat utama bagi seseorang yang ingin menjadi seorang auditor eksternal. Sebab dengan profesionalisme yang tinggi kebebasan auditor akan semakin terjamin. Untuk menjalankan perannya yang menuntut tanggung jawab yang semakin luas, auditor eksternal harus memiliki wawasan yang luas tentang kompleksitas organisasi modern.

Sukriah dkk (2009) menjelaskan bahwa semakin besar tingkat objektivitas seorang auditor maka semakin baik kualitas hasil audit. Dengan kata lain, semakin besar tingkat objektivitas auditor maka semakin baik kualitas hasil pemeriksaan atau kinerjanya. Demikian sebaliknya bila objektivitas rendah/buruk maka kinerja auditor akan buruk/rendah.

Laporan audit adalah proses akhir dari keseluruhan proses audit. Bagian yang terpenting yang merupakan informasi utama dari laporan audit adalah opini audit. Menurut standar profesional akuntan publik (PSA 29 SA Seksi 508), ada lima (5) jenis opini auditor, yaitu Pendapat Wajar Tanpa Pengecualian (WTP), Pendapat Wajar Tanpa Pengecualian Dengan Bahasa Penjelasan, Pendapat Wajar dengan Pengecualian, Pendapat Tidak Wajar, dan Tidak Memberikan Pendapat.

Berdasarkan uraian diatas, penelitian ini bermaksud untuk meneliti kembali faktor-faktor yang mempengaruhi kinerja auditor. Dengan menggunakan variabel yang tidak sama dari penelitian terdahulu agar dapat memberikan informasi mengenai faktor-faktor yang mempengaruhi opini auditor. Untuk itu penulis melakukan penelitian yang berjudul : “ Pengaruh 
Vol.1, No.3, Sept 2018

\section{profesionalisme, dan objektifitas auditor terhadap ketepatan pemberian opni audit"}

\section{LANDASAN TEORI}

\subsection{Teori Etika Profesi}

Etika dalam bahasa Yunani terdiri dari dua kata yaitu: etos berarti kebiasaan atau adat, dan ethiokos berarti perasaan batin atau kecenderungan batin mendorong manusia dalam bertingkah laku.

Penelitian etika (akuntan) di Indonesia telah banyak dilakukan. Namun penelitian ini masih terbatas pada aspek kognitif akuntan (berkaitan dengan pengambilan keputusan etis). Penelitian ditekankan pada aspek kognitif tersebut refrensi utamanya adalah Theory of Moral Reasoning yang dikembangkan oleh Kohlberg dan Defining Issues Tes (DIT) yang dikembangkan oleh Rest. Mendasarkan pada kedua model ini, penelitian etika pada umumnya mengembangkan instrument yang berisi situasi pengambilan keputusan etis dan pendekatanya positivistik.

Diskusi tentang etika telah berlangsung selama berabad-abad semenjak jaman Yunani Kuno. Berbagai aliran pemikiran etika dalam mengkaji moralitas suatu tindakan telah berkembang sedemikian luasnya. Berdasarkan historisnya, pemikiran-pemikiran etika berkembang meliputi aliran-aliran etika klasik yang berasal dari pemikiran para filosof Yunani, etika kontemporer dari pemikiran Eropa abad pertengahan sampai abad 20-an, serta aliran etika dari pemikiran kelangan agamawan Islam yang selalu mengacu pada Al-Qur'an dan As-Sunah (Ludigdo, 2006).

Untuk kalangan professional, dimana pengaturan etika dibuat untuk menghasilkan kinerja etis yang memadai maka kemudian asosiasi profesi merumuskan suatu kode etik. Kode etik profesi dan sebagai dasar terbentuknya kepercayaan masyarakat karena dengan mematuhi kode etik, akuntan diharapkan dapat menghasilkan kualitas kinerja yang paling baik bagi masyarakat (Baidaie, 2000 dalam Ludigdo, 2006). Dalam kerangka inilah Akuntan Indonesia (IAI) merumuskan suatu kode etik yang harus dipedomani oleh semua anggota, serta aturan etika dan interpretasi aturan etika yang wajib dipatuhi oleh masing-masing anggota kompartemen.

\subsection{Profesionalisme}

Profesionalisme adalah perilaku bertangung jawab terhadap apa yang telah dikerjakan kepadanya. Sikap profesionalisme akan mengambil keputusan berdasarkan pertimbangan yang dimilikinya yaitu berdasarkan yang pertama pengabdian pada profesi, auditor yang mengabdi kepada profesinya akan melakukan totalitas kerja dimana dengan totalitas ini dia akan lebih hati-hati dan bijaksana dalam melakukan audit sehinga dapat menghasilkan audit yang berkualitas. Jadi apabila semakin tinggi pengabdian pada profesi akan semakin tinggi profesionalisme auditor Ni Made Ayu Lestari (2013:5). 
Faktor yang mempengaruhi opini audit adalah profesionalisme. Surya dan alwani (2007:28) dalam Yulfa Zailia (2013: 4), ada dua tangung jawab yang harus dipikul oleh akuntan publik dalam menjalankan pekerjaan profesionalnya, yaitu pertama, menjaga kerahasiaan informasi yang diperoleh dalam melaksanakan tugasnya. Informasi yang diperoleh akuntan publik selama ia menjalankan pekerjaannya tidak boleh diungkapkan oleh pihak ketiga, kecuali atas ijin kliennya. Namun jika hukum atau negara menghendaki akuntan publik mengungkapkan informasi yang diperolehnya selama penugasannya, akuntan publik berkewajiban untuk mengungkapkan informasi tersebut tanpa harus mendapatkan persetujuan dari kliennya. Tangung jawab yang kedua yaitu menjaga mutu profesinalnya. Setiap akuntan publik harus bisa mempertangung jawabkan mutu pekerjaan atau pekerjaan lain pada saat yang bersamaan, yang bisa menyebabkan penyimpangan obyektivitas atau ketidak konsistenan dalam pekerjaannya.

IAPI sebagai organisai yang dapat menetapkan standar dan aturan yang harus dipatuhi oleh seluruh anggota termaksud setiap kantor akuntan publik lain yang beroperasi sebagai auditor independen. Persyaratan-persyaratan ini dirumuskan oleh komite-komite yang dibentuk oleh IAPI. Ada tiga bidang utama dimana IAPI berwenang menetapkan standar dan memuat aturan yang bisa meningkatkan perilaku profesional sebagai auditor.

1) Standar Auditing. Komite Standar Profesional Akuntan Publik (Komite SPAP) IAPI bertangung jawab untuk menerbitkan standar auditing. Standar ini disebut sebagai Peryataan Standar Auditing atau PSA (sebelumnya disebut NPA dan PNPA). Di Amerika Serikat peryataan in disebut sebagai SAS (Statement on Auditing Standar) yang dikeluarkan oleh ASB (Auditing Standar Boards). Pada tanggal 10 November 1993 dan 1 Agustus 1994 pengurus pusat IAPI telah mengesahkan sejumlah peryataan standar auditing. Penyempurnaan ini terutama sekali bersumber pada SAS dengan penyesuain terhadap kondisi Indonesia dan standar auditing internasional.

2) Standar kompikasi dan penelaahan laporan keuangan. Komite SPAP IAPI dan Compilation and Review Standards Committee bertangung jawab untuk mengeluarkan peryataan mengenai pertangung jawaban akuntan publik sehubungan dengan laporan keuangan suatu perusahaan yang tidak diaudit. Peryataan ini di Amerika Serikat disebut Statements on Standards for Accounting and Review Services (SSARS) dan di Indonesia disebut Peryataan Standar Jasa Akuntansi dan Review (PSAR). PSAR 1 dipisahkan pada 1 agustus 1994 mengantikan peryataan NPA sebelumnya mengenai hal yang sama. Bidang ini mencakup dua jenis jasa, pertama, untuk situasi dimana akuntan membantu kliennya menyusun laporan keuangan tanpa memberikan jaminan mengenai isinya (jasa kompilasi). Kedua, untuk situasi dimana akuntan melakukan prosedur-prosedur pengajuan peryataan dan analisis tertentu, sehinga dapat memberikan suatu keyakinan terbatas bahwa tidak diperlukan perubahan apapun terhadap laporan keuangan bersangkutan (jasa review). 


\subsection{Objektifitas}

Obyektifitas merupakan kebebasan sikap mental yang harus dipertahankan oleh auditor dalam melakukan audit, dan auditor tidak boleh membiarkan pertimbangan auditnya dipengaruhi oleh orang lain. Setiap auditor harus menjaga obyektifitas dan bebas dari benturan kepentingan dalam pemenuhan kewajibannya (Prinsip Etika Profesi Ikatan Akuntan Indonesia, 1998 dalam Mulyadi, 2002). Dalam prinsip tersebut dinyatakan obyektifitas adalah suati kualitas yang memberikan nilai atas jasa yang diberikan. Prinsip obyektifitas mengharuskan anggota bersikap adil, tidak memihak, jujur secara intelektual, tidak berprasangka, serta bebas dari benturan kepentingan atau berada di bawah pengaruh pihak lain (Mulyadi, 2002).

Lebih lanjut (Mulyadi, 2002) menjelaskan, dalam menghadapi situasi dan praktik yang secara spesifik berhubungan dengan aturan etika sehubungan dengan obyektifitas, yang harus cukup dipertimbangkan adalah sebagai berikut :

1) Adakalanya auditor dihadapkan kepada situasi yang memungkinkan mereka menerima tekanan-tekanan yang diberikan kepadanya. Tekanan ini dapat mengganggu obyektifitasnya.

2) Adakalanya tidak praktis untuk menyatakan dan menggambarkan semua situasi di mana tekanan-tekanan mungkin terjadi. ukuran kewajaran harus digunakan dalam menentukan standar untuk mengidentifikasi hubungan yang mungkin atau kelihatan dapat merusak obyektifitas.

3) Hubungan-hubungan yang memungkinkan prasangka, bias atau pengaruh lainnya untuk melanggar obyektifitas harus dihindari.

4) Memiliki kewajiban untuk memastikan bahwa orang-orang yang terlibatdalam pemberian jasa professional mematuhi prinsip obyektifitas.

5) Tidak boleh menerima atau menawarkan hadiah atau entertainment yang dipercaya dapat menimbulkan pengaruh yang tidak pantas terhadap pertimbangan professional mereka atau terhadap orang-orang yang berhubungan dengan mereka, dan harus menghindari situasi-situasi yang dapat membuat posisi professional mereka ternoda.

\subsection{Ketepatan Pemberian Opini Audit}

1) Ketepatan

Menurut Adam (2011: 23), ketepatan (akurasi) adalah kesamaan atau kedekatan suatu hasil pengukuran dengan angka atau data yang sebenarnya (true value / correct result).

Menurut Rahmat (2005-2012) dalam deva (2010: 39), ketepatan (akurasi) yaitu Informasi harus bebas dari kesalahan-kesalahan dan tidak bias atau menyesatkan. Ketepatan juga berarti informasi harus jelas mencerminkan maksudnya. Informasi harus akurat karenan dari sumber informasi sampai kepenerima informasi kemungkinan banyak terjadi gangguan (noise) yang dapat berubah atau merusak informasi tersebut.

2) Pemberian Opini Audit 
Pada akhir pemeriksaannya, dalam suatu pemeriksaan umum (general audit), KAP akan memberikan suatu laporan akuntan yang terdiri dari:

1) Lembaran opini, yang merupakan tanggung jawab akuntan publik, dimana akuntan publik memberikan pendapatnya terhadap kewajaran laporan keuangan yang disusun oleh manajemen dan merupakan tanggung jawab manajemen.

2) Laporan keuangan terdiri dari:

a) Neraca

b) Laporan laba-rugi

c) Laporan perubahan ekuitas

d) Laporan arus kas

e) Catatan atas laporan keuangan, yang antara lain berisi: bagian umum (menjelaskan latar belakang perusahaan), kebijakan akuntansi dan penjelasan atas pos-pos neraca dan laba rugi.

f) Informasi tambahan berupa lampiran mengenai perincian pos-pos yang penting seperti perincian piutang, aktiva tetap, utang, beban umum dan administrasi serta beban penjualan.

\section{METODE PENELITIAN}

\subsection{Rerangka Pemikiran}

Hubungan antar variabel dalam penelitian ini telah digambarkan dalam model penelitian sebagai berikut :

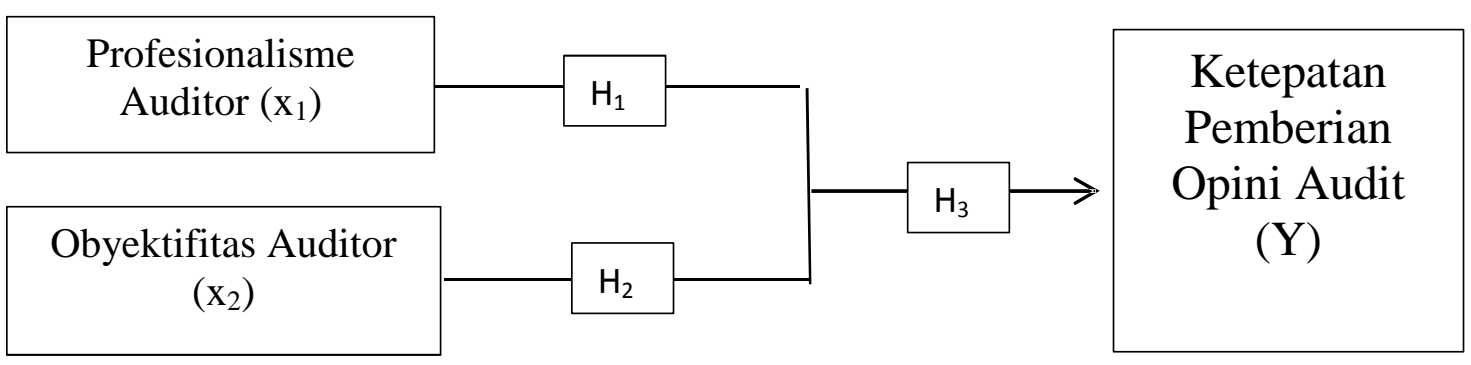

Gambar 3.1

Model Konseptual Penelitian

\subsection{Hipotesis Penelitian}

Berdasarkan latar belakang masalah, maka dirumuskan hipotesis sebagai berikut :

$\mathrm{Ha}_{1}$ : Terdapat pengaruh negatif antara profesionalisme auditor 
terhadap ketepatan pemberian opini audit secara parsial

$\mathrm{Ha}_{2}$ : Terdapat pengaruh negatif antara objektifitas auditor terhadap ketepatan pemberian opini audit secara parsial.

$\mathrm{Ha}_{3}$ : Terdapat pengaruh positif antara profesionalisme, objektifitas, auditor terhadap ketepatan pemberian opini audit secara simultan.

\section{HASIL PENELITIAN}

\subsection{Hasil Uji Statistik Deskriptif}

\section{1) Profesionalisme}

Pada bagian ini akan diuraikan distribusi jawaban responden untuk variabel professional yang diperoleh dari hasil pengambilan data melalui kuisioner. Dimana jawaban Sangat Tidak Setuju (STS) diberi nilai 1, Tidak Setuju (TS) diberi nilai 2, Netral (N) diberi nilai 3, Setuju (S) diberi nilai 4, dan Sangat Setuju (SS) diberi nilai 5.

Tabel 4.1

Distribusi jawaban responden pada instrumen

Variabel professional

\begin{tabular}{|c|c|c|c|c|c|c|c|}
\hline No & Pernyataan & STS & TS & $\mathbf{N}$ & $\mathbf{S}$ & SS & Mean \\
\hline \multirow{6}{*}{1} & $\begin{array}{l}\text { Pengabdian pada } \\
\text { profesi }\end{array}$ & & & & & & \\
\hline & a. $\quad \mathrm{P} 1$ & 0 & 0 & 5 & 28 & 45 & 4.51 \\
\hline & b. $\quad \mathrm{P} 2$ & 0 & 0 & 4 & 57 & 17 & 4.11 \\
\hline & c. $\quad$ P3 & 0 & 5 & 33 & 22 & 18 & 3.68 \\
\hline & d. $\quad \mathrm{P} 4$ & 0 & 0 & 28 & 20 & 30 & 4.03 \\
\hline & e. P5 & 0 & 0 & 25 & 28 & 25 & 4.00 \\
\hline \multirow{6}{*}{2} & $\begin{array}{l}\text { Hubungan dengan } \\
\text { rekan seprofesi }\end{array}$ & & & & & & \\
\hline & a. $\quad$ P6 & 0 & 0 & 18 & 27 & 33 & 4.19 \\
\hline & b. P7 & 0 & 0 & 12 & 22 & 44 & 4.41 \\
\hline & c. $\quad$ P8 & 0 & 0 & 7 & 30 & 41 & 4.44 \\
\hline & d. $\quad$ P9 & 0 & 0 & 4 & 10 & 35 & 4.32 \\
\hline & e. $\mathrm{P} 10$ & 0 & 0 & 5 & 34 & 39 & 4.44 \\
\hline \multicolumn{2}{|r|}{ Total } & $\mathbf{0}$ & 5 & 141 & 278 & 327 & 4.21 \\
\hline \multicolumn{2}{|r|}{ Prosentase $(\%)$} & $\mathbf{0}$ & 0.67 & 18.77 & 37.02 & 43.54 & - \\
\hline
\end{tabular}

Sumber : Hasil penelitian yang diolah 2017

Berdasarkan hasil diatas, dapat diketahui bahwa jawaban responden sebagian besar mengarah pada jawaban sangat setuju (SS) yaitu sebesar 
43,54\%. Dengan nilai rata - rata 4,21 berarti secara umum responden cenderung memiliki respon yang sangat baik (sangat setuju) terhadap sikap profesionalisme auditort. Secara khusus, dalam hal profesionalisme dari pernyataan 1 sampai dengan 10 responden lebih setuju bahwa Sikap profesionalisme akan mengambil keputusan berdasarkan pertimbangan yang dimilikinya yaitu berdasarkan yang pertama pengabdian pada profesi, auditor yang mengabdi kepada profesinya akan melakukan totalitas kerja dimana dengan totalitas ini dia akan lebih hati-hati dan bijaksana dalam melakukan audit sehinga dapat menghasilkan audit yang berkualitas.

\section{2) Objektifitas}

Pada bagian ini akan diuraikan distribusi jawaban responden untuk variabel professional yang diperoleh dari hasil pengambilan data melalui kuisioner. Dimana jawaban Sangat Tidak Setuju (STS) diberi nilai 1, Tidak Setuju (TS) diberi nilai 2, Netral (N) diberi nilai 3, Setuju (S) diberi nilai 4, dan Sangat Setuju (SS) diberi nilai 5.

Tabel 4.2

Distribusi jawaban responden pada instrumen Variabel objektifitas

\begin{tabular}{|c|c|c|c|c|c|c|c|}
\hline No & Pernyataan & STS & TS & $\mathbf{N}$ & $\mathbf{S}$ & SS & Mean \\
\hline \multirow[t]{5}{*}{1} & $\begin{array}{l}\text { Bebas dari benturan } \\
\text { kepentingan }\end{array}$ & & & & & & \\
\hline & a. $\mathrm{P} 1$ & 0 & 0 & 10 & 33 & 35 & 4.32 \\
\hline & b. $\quad$ P2 & 0 & 0 & 32 & 23 & 23 & 3.88 \\
\hline & c. $\mathrm{P} 3$ & 0 & 0 & 4 & 57 & 17 & 4.17 \\
\hline & $\begin{array}{ll}\text { d. } & \text { P4 } \\
\end{array}$ & 0 & 0 & 28 & 20 & 30 & 4.03 \\
\hline \multirow[t]{5}{*}{2} & $\begin{array}{l}\text { Pengungkapan } \\
\text { kondisi sesuai fakta }\end{array}$ & & & & & & \\
\hline & a. $\mathrm{P5}$ & 0 & 0 & 20 & 20 & 38 & 4.23 \\
\hline & b. $\quad$ P6 & 0 & 0 & 5 & 34 & 39 & 4.44 \\
\hline & c. $\quad$ P7 & 0 & 0 & 28 & 20 & 30 & 4.03 \\
\hline & d. $\quad$ P8 & 0 & 0 & 18 & 25 & 35 & 4.22 \\
\hline \multicolumn{2}{|r|}{ Total } & $\mathbf{0}$ & $\mathbf{0}$ & 145 & 232 & 247 & 4.17 \\
\hline \multicolumn{2}{|r|}{ Prosentase (\%) } & $\mathbf{0}$ & $\mathbf{0}$ & 23.2 & 37.2 & 39.6 & - \\
\hline
\end{tabular}

Sumber : Hasil penelitian yang diolah 2017

Berdasarkan hasil tabulasi data diatas, dapat diketahui bahwa jawaban responden sebagian besar mengarah pada jawaban sangat setuju (SS) yaitu sebesar 39,6\%. Dengan nilai rata - rata 4,17 berarti secara umum responden cenderung memiliki respon yang sangat baik (sangat setuju) terhadap sikap objektifitas auditort. Secara khusus, dalam hal objektifitas dari pernyataan 1 sampai dengan 8 responden lebih setuju bahwa Sikap objektifitas mengharuskan auditor bersikap adil, tidak memihak, jujur secara intelektual, tidak berprasangka, serta bebas dari benturan kepentingan atau berada di bawah pengaruh pihak lain. 


\subsection{Uji T}

Tabel 4.3 dibawah ini menunjukan bahwa variabel profesionalisme dan objektifitas auditor berpengaruh terhadap variabel ketepatan pemberian opini audit.

Tabel 4.3 Hasil Uji Statistik t

Coefficients $^{a}$

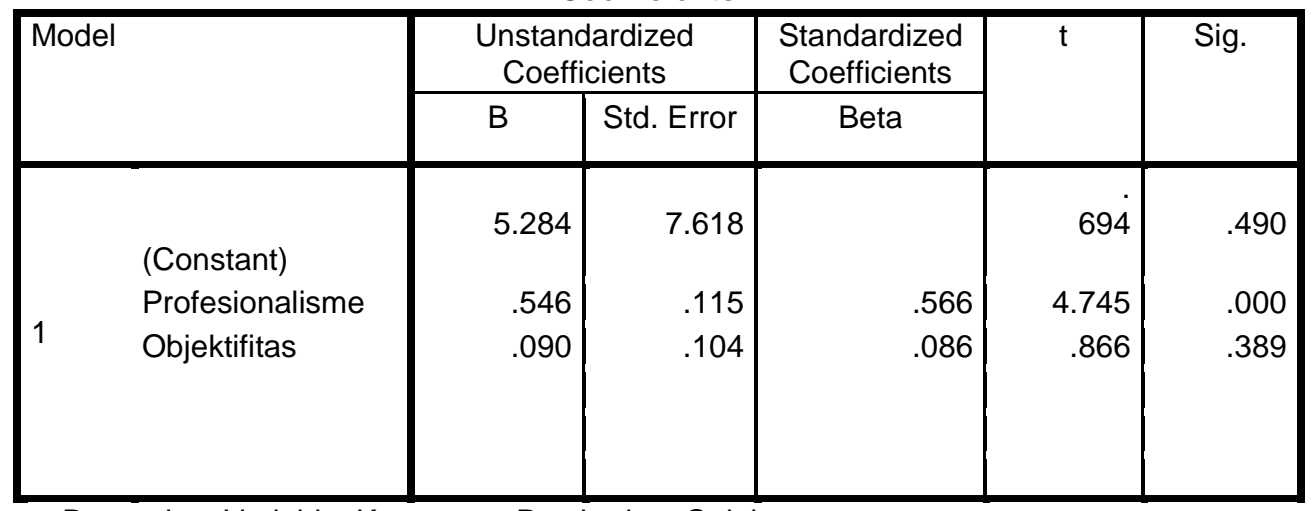

a. Dependent Variable: Ketepatan_Pemberian_Opini

Sumber : Data primer yang diolah dengan spss

\section{Hasil Uji Hipotesis 1 : Pengaruh profesionalisme terhadap ketepatan pemberian opini audit}

Hasil hipotesis 1 dapat dilihat pada table 4.3, variabel profesionalisme mempunyai tingkat signifikansi sebesar 0,000 . Hal ini berarti menerima $\mathrm{H}_{1}$, maka dapat disimpulkan bahwa variabel profesionalisme berpengaruh secara signifikan terhadap ketepatan pemberian opini audit karenan tingkat signifikansi yang dimilik variabel profesionalisme lebih kecil dari 0,05

\section{Hasil Uji Hipotesis 2 : Pengaruh Objektifitas terhadap ketepatan pemberian opini audit}

Hasil hipotesis 2 dapat dilihat pada table 4.3, variabel objektifitas mempunyai tingkat signifikansi sebesar 0,389. Hal ini berarti menolak $\mathrm{H}_{2}$, maka dapat disimpulkan bahwa variabel objektifitas tidak berpengaruh secara signifikan terhadap ketepatan pemberian opini audit karenan tingkat signifikansi yang dimilik variabel objektifitas lebih besar dari 0,05.

\subsection{Uji Regresi Linier Berganda}

Uji regresi linier berganda merupakan untuk mencari apakah ada pengaruh yang signifikan antara sikap profesionalisme dan objektifitas, auditor terhadap ketepatan pemberian opini audit yang diberikan.

Tabel 4.4 Uji Regresi Linier Berganda

\begin{tabular}{|l|c|c|c|c|c|}
\hline Model & \multicolumn{2}{|c|}{$\begin{array}{c}\text { Unstandardized } \\
\text { Coefficients }\end{array}$} \\
\cline { 1 - 5 } & B & $\begin{array}{c}\text { Standardized } \\
\text { Coefficients }\end{array}$ & Sig. \\
\cline { 1 - 5 } & Std. Error & Beta & \\
\hline
\end{tabular}




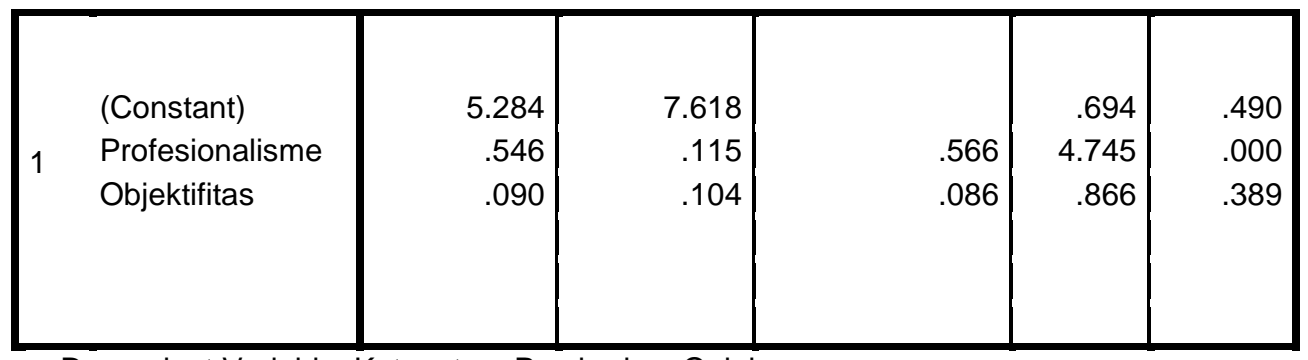

a. Dependent Variable: Ketepatan_Pemberian_Opini

Dari tabel di atas diperoleh hasil persamaan regresi linier berganda yang terbentuk adalah $\mathrm{Y}=, 5,285+0,546 \mathrm{x}_{1}+0,090 \mathrm{x}_{2}$ yang artinya:

1) Konstanta $\mathrm{Y}$ (a) sebesar 5,285 artinya jika sikap profesionalisme $\left(\mathrm{x}_{1}\right)$ objektifitas $\left(\mathrm{x}_{2}\right)$ nilainya adalah 0 , maka ketepatan pemberian opini (Y) nilainya sebesar 5,285.

2) Koefisien regresi Koefisien regresi variabel sikap profesionalisme $\left(\mathrm{x}_{1}\right)$ sebesar 0,546 artinya jika sikap profesionalisme mengalami kenaikan sebesar 1, maka ketepapatan pemberian opini akan mengalami kenaikan sebesar 0,546. Koefisien bernilai positif artinya terjadi hubungan positif antara sikap profesionalisme dengan ketepatan pemberian opini (Y).

3) Koefisien regresi variabel sikap Objektifitas $\left(\mathrm{x}_{2}\right)$ sebesar 0,090 artinya jika sikap objektifitas mengalami kenaikan sebesar 1, maka ketepapatan pemberian opini akan mengalami kenaikan sebesar 0,090. Koefisien bernilai positif artinya terjadi hubungan positif antara sikap objektifitas dengan ketepatan pemberian opini (Y).

\section{KESIMPULAN}

1) Berdasarkan kesimpulan di atas, menunjukan bahwa variabel objektifitas auditor, tidak berpengaruh secara signifikan terhadap ketepatan pemberian opini audit. Disarankan bahwa auditor dalam menjalankan tugasnya dalam melakukan audit, dengan adannya suatu keharusan yang mutlak tersebut membuat auditor agar senantiasa secara terus-menerus melakukan proses belajar dan mencari pengalaman yang sebanyakbanyaknya. Sebab tidak dapat diragukan lagi bahwa objektifitas tidak hanya diperoleh dari dunia akademik atau pendidikan formal, tetapi juga dapat terus ditingkatkan dan di kembangkan melalui pengalaman audit..

2) Kantor Akuntan Publik (KAP) juga harus memberikan penugasan yang lebih banyak kepada para auditornya agar dapat menambah pengetahuan dan pengalaman mereka dalam mengaudit. Pengetahuan dan pengalaman audit yang memadai juga diperlukan untuk menentukaan keputusaan dan menganalisis masalah terutama masalah yang jarang terjadi seperti hal-hal yang mengakibatkan tidak tepatnya opini audit yang diberikan, semakin banyak pengetahuan dan pengalaman auditor maka semakin tepat dalam memberikan penjelasan dari berbagai macamtemuan audit. 
Vol.1, No.3, Sept 2018

\section{DAFTAR PUSTAKA}

Ahmad A.K. Muda. (2006). Kamus Lengkap Bahasa Indonesia. Jakarta: Reality Publisher.

Aren, Alvin A. Elder, Randal J dan Beasley, Mark S. 2008. "Auditing dan Jasa Asuransi Pendekatan Terintegrasi”. Jilid 2,Edisi Keduabelas, Erlangga.

Boynton, et. Al. “Modern auditing”. Edisi kedelapan, Erlangga, 2006.

Bustami, Afif. (2013). Skripsi, "Pengaruh Independensi, Akuntabilitas dan Profesionalisme auditor Terhadap Kualitas Audit". Fakultas ekonomi dan bisnis Universitas Islam Negri Syarif Hidayatullah. Jakarta .

Elfarina, Christina, Eunike. (2007). Pengaruh Kompetensi dan Independensi Auditor Terhadap Kualitas Audit. Semarang. Skripsi S1 : Universitas Negri Semarang

Ghozali, Imam, (2009). Aplikasi Analisis Multivariate dengan Program SPSS”. Badan Penerbitan Universitas Dipenogoro, Semarang.

Gusti, Maghfirah dan Syahril Ali. (2008). Hubungan Skeptisme Profesional Auditor dan Situasi Audit, Etika, Pengalaman serta Keahlian Audit dengan Ketepatan Pemberian Opini Auditor oleh Akuntan Publik", Simposium Nasional Akuntansi XI, Universitas Andalas, Pontianak.

Harahap, Sofyan Syafri. (2007). Teori Akuntans. edisi revisicetakan . PT RajaGrafindo Persada.Jakarta.

Harhinto, Teguh (2004). Pengaruh Keahlian dan Independensi Terhadap Kualitas Kualitas Audit Studi Empiris Pada KAP di Jawa Timur”. Semarang. Tesis Maksi : Universitas Diponegoro.

Herawaty, Arleen Dkk.(2008). Profesionalisme, Pengetahuan Akuntan Publik dalam Mendeteksi Kekeliruan, Etika Profesi dan Pertimbangan Tingkat Materialitas. The $2^{\text {rd }}$ Nasional Conference UKWMS Surabaya.

Herliansyah, Yudhi dan Ilyas, Meifda. Pengaruh Pengalaman Auditor terhadap Penggunaan Bukti Tidak Relevan dalam Auditor Judgement. Simposium Nasional Akuntansi IX Padang. Universitas Mercu Buana. 23-26 Agustus 2006.

Ikatan Akuntan Publik. 2006. Standar Profesional Akuntan Publik-SPAP

Institut Akuntan Publik Indonesia. (2011). Standar Profesional Akuntan Publik. Salemba Empat, Jakarta.

Ludigdo, Unti. Strukturasi Praktik Etika di Kantor Akuntan Publik Sebuah Studi Interpretif. Simposium Nasional Akuntansi 9. Padang. Agustus 2006.

Megasari, Devi. Pengaruh Etika, Keahlian Audit, dan Independensi terhadap opini Audit. Skripsi. Universitas Islam Negri Syarif Hidayatullah, Jakarta. 2008.

Pribadi prasetyo, Anggun. (2010). Pengaruh locu of control, pengalaman auditor, komitmen professional dan etika professional terhadap 
perilaku auditor dalam situasi konflik audit. Skripsi. Universitas Islam Negri Syarif Hidayatullah, Jakarta.

Rahayu, Siti Kurnia dan Suhayati, Elly. (2010). Auditing: Konsep Dasar dan Pendoman Pemeriksaan Akuntan Publik. Edisi Pertama, Graha Ilmu, Yogyakarta.

Rasul, Syahrudin. (2005). Pengintegrasian Sistem Akuntabilitas Kinerja dan Anggaran dalam Perspektif UU NO. 17/2003 Tentang Keuangan Negara. Jakarta: PNRI.

Sabrina dan Indira Januarti. (2012). Pengaruh Pengalaman, Keahlian, Situasi Audit, Etika, dan Gender terhadap Ketepatan Pemberian Opini Audit melalui Skeptisme profesional Auditor (Studi Kasus pada KAP Big Four di Jakarta”. Simposium Nasional Akuntansi XV, Banjarmasin.

Singgih, Elisha Muliani dan Bawono, Icuk Rangga. (2010). Pengaruh Independensi, Pengalaman, Due Profesional Care dan akuntabilitas terhadap Kualitas audit (Studi pada Auditor di KAP "Big Four' di Indonesia). Simposium Nasional Akuntansi XIII Purwokerto.

Sugiyono. (2011). Metode Penelitian Kuantitatif, Kualitatif, dan R\&D. Alfabeta. Bandung.

Sunyoto, Danang. (2014). Auditing Pemeriksaan Akuntansi. CAPS ( Center of Academic Publising Service: Yogyakarta.

Suraida, Ida. (2005). Pengaruh Etika, Kompetensi, Pengalaman Audit dan Risiko Audit terhadap Skeptisme Profesional Auditor dan Ketepatan Pemberian Opini Akuntan Publik. Sosiohumaniora, vol 7 no. 3, Bandung.

Sukriah, et. al. (2009). Pengaruh Pengalaman Kerja, Independensi, Obyektifitas, Integritas dan Kompetensi terhadap Kualitas Hasil Pemeriksaan. Simposium Nasional Akuntansi XXI, Palembang.

Yendrawati, Reni, "Analisis Hubungan Antara Profesionalisme Auditor dengan Pertimbangan Tingkat Materialitas dalam Proses Pengauditan Laporan Keuangan”. Dalam Jurnal Fenomena : Vol. 6 No.1, 2008.

Wahyudi, Hendro dan Mardiyah, Aida Ainul.(2006). Pengaruh Profesionalisme Auditor terhadap Tingkat Materialitas dalam Pemeriksaan Laporan Keuangan. Simposium Nasional Akuntansi IX Padang. STIE Malangkuçeçwara Malang.

Zailia, Yulfa. (2013). Skripsi . Pengaruh etika,profesionalisme dan pengalaman audit terhadap katepatan pemberian opini akuntan publik. Fakultas ekonomi dan bisnis Universitas Islam Negri Syarif Hidayatullah. Jakarta . 